\title{
Treatment Coverage and Reimbursement
}

\author{
Cornelie Haag
}

The conditions for reimbursement for CAR-T cell therapy are not uniform in Europe. Most European countries use a DRG system for billing hospital services, but the details vary. Nonetheless, the similarity is that expensive therapies, such as CAR-T cell therapy, are initially not included in the DRG system. Most countries possess instruments to ensure the financing of such expensive therapies outside the DRG system as separate payments. These reimbursement instruments of DRG systems are used in most countries both for short-term financing for innovative and new therapies and as long-term additional fees within the respective DRG system. Individual countries maintain different regulations, and therefore, hospitals have the responsibility to determine the specific requirements of their country before establishing CAR-T cell therapy.

One should consider that other significant costs exist in addition to the price of the actual CAR-T cell product, which has been agreed upon with the pharmaceutical industry. In addition to the usual hospitalization costs, the price of the inpatient stay for the administration of CAR-T cells can include the costs for intensive care and expensive medication, such as tocilizumab. These additional costs are generally reimbursed through the established system in each country. However, at least 2 years are required to integrate the costs of a new therapy or method into the existing DRG.

The special feature of CAR-T cell therapy is that the hospital needs to collect lymphocytes from the patient in advance through apheresis. This initial product for the production of CAR-T cells induces further costs that are usually not reimbursed.

The implementation of this new therapy in a hospital should not be underestimated. In addition to the training of staff for this new type of therapy, high demands are placed on quality management by both the pharmaceutical industry and the government. These structural costs (mostly personnel costs) for the hospital must be

C. Haag $(\bowtie)$

University Hospital Carl Gustav Carus Dresden, Dresden, Germany

e-mail: Cornelie.Haag@uniklinikum-dresden.de 
agreed upon separately with health insurance companies or the government, depending on the state-dependent reimbursement system.

A single hospital has a minor impact on the pricing of a CAR-T cell product; this is usually done by negotiation between pharmaceutical companies and government agencies.

In addition to the reimbursement of the CAR-T cell product at the price set by these negotiations, the additional costs of this therapy are reimbursed differently, particularly within Germany. Efforts are being made to centralize these negotiations, but the success of such a centralized negotiation depends on the structures and organization of the numerous health insurance companies in Germany.

In Germany, the individual hospital then becomes responsible for the specific reimbursement of costs for each individual patient. In the case of extremely high costs, advanced agreements are usually made between the health insurance and the hospital.

Before initiating CAR-T cell therapy, every doctor or hospital should be aware of the different regulations in each country to avoid not receiving reimbursement for this expensive therapy.

\section{Key Points}

- Different rules in different countries.

- Additional costs aside from the cost of the CAR-T cell product.

Open Access This chapter is licensed under the terms of the Creative Commons Attribution 4.0 International License (http://creativecommons.org/licenses/by/4.0/), which permits use, sharing, adaptation, distribution and reproduction in any medium or format, as long as you give appropriate credit to the original author(s) and the source, provide a link to the Creative Commons license and indicate if changes were made.

The images or other third party material in this chapter are included in the chapter's Creative Commons license, unless indicated otherwise in a credit line to the material. If material is not included in the chapter's Creative Commons license and your intended use is not permitted by statutory regulation or exceeds the permitted use, you will need to obtain permission directly from the copyright holder.

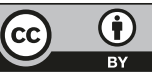

